\title{
The Effectiveness of Environment-based Reading Material in Increasing Students' Vocabulary in EFL Learning in the Eighth Grade of Sumbawa District Junior High School
}

\author{
Umar \\ STKIP Paracendekia N W Sumbawa, Indonesia \\ Nengah Sudipa \\ Udayana University, Indonesia
}

\begin{abstract}
The present study is an attempt to examine the competence of vocabulary of the Eighth Grade of Junior High School in the Sumbawa District. The study used environment-based reading material. The study indicates the levels of English vocabulary among 128 Grade 8 junior high school students in the Sumbawa District. The EFL learners of Sumbawa District were divided into four environment-based groups, namely; environment-based urban, represented by SMPN 2 Sumbawa $(n=32)$, environment-based marine, represented by SMPN 4 Lab. Badas (n=32), environment-based urban, represented by SMPN 1 Moyo Hulu (n=32), and environment-based rural, represented by SMPN 1 Lopok $(n=32)$. The quantitative descriptive research design was used to collect data pre- and post-test. The tests were multiple-choice, using environment-based reading material. Effectiveness was measured by comparing pre-test, post-test, and paired samples t-test. Based on the result of data analysis, it is evident that the Environment-based reading material was significant for Grade 8 of Junior High Schools in the Sumbawa District. Students who participated in an environmentally based reading program recorded an increased competency when compared with students outside the program.
\end{abstract}

Index Terms - environment-based reading, EFL learners, vocabulary competence

\section{INTRODUCTION}

The English language has an essential role throughout the world, in the field of education. In Indonesia, English is a foreign language. It is, however, taught as a compulsory subject in junior and senior high schools. Moreover, English is one of the subjects included in the national examination and Indonesian government policy supports the development of English language learning. This is supported by Satyawati (2019, p. 244), states that English as a foreign language is only used for learning at school.

In all language learning, including English as a second language, four skills must be mastered by learners, one of which is reading. This is in line with Asmawati (2015, p. 69), who claims that reading is one of the four necessary language skills for those learning English as a second or foreign language (ESL/EFL). It is also supported by Thao (2014, p. 1283), that reading is an important receptive language skill since it enhances students' pool of information to augment the quality of the product of other language skills.

Reading cannot be separated from daily activity because the main goal of reading is comprehension. Almost all people get information from reading. People read many kinds of text, such as newspapers, magazines, novels, articles, academic books, etc. This is supported by Akyol, (2014, p. 200), who says that, the effective use of these skills in a reading environment enables the reader to comprehend the text. It also supported by Sanati (2020, pp. 82), who says that, reading is the basis of instruction in all aspects of language learning: using textbooks for language courses, writing, revising, developing vocabulary, acquiring grammar, editing, and using computer-assisted language learning programs.

Reading in English as a foreign language is not the same as reading in the student's mother tongue, and teaching material does not allow for differences in students' environment. This means that students often encounter difficulties in vocabulary, structure, pronunciation, etc. which may lead to boredom. In the preliminary study of Grade 8, Lopok Junior High School, some difficulties in reading were found. These were mainly due to the paucity of vocabulary and the lack of relevant, stimulating reading materials. According to Tanyer $(2014$, p. 37), vocabulary has been problematic for EFL (English as a Foreign Language) learners since they need to acquire a large amount of vocabulary to be able to communicate successfully. This is in line with Alqahtani $(2015$, p. 2), that teaching vocabulary is one of the most discussed parts of teaching English as a foreign language.

Pietilä (2014, p. 26), states that the relationship between foreign language vocabulary knowledge and reading is at least twofold and reciprocal, while Taheri (2014, p. 545) says that learning vocabulary is a part of learning any language, 
one should think of the way to achieve that goal. Bai (2018, p. 853), further states that vocabulary is one of the three elements of language, the building material and the basis of language. That the selection of EFL reading materials is equally important, was supported by Mokhtari (2014, p. 163).

Furthermore, foreign language teachers are challenged to provide exposure to language; and to provide opportunities for learning through classroom activities. In class, teachers play a significant role in bringing, to students, the idea that language learning can be fun. Therefore, teachers need to encourage students to develop the skills which will improve their ability and will to read. According to Duff (2015, p. 854), reading text can provide key opportunities for advancement in vocabulary development.

Taking these ideas into consideration, teachers can create effective strategies, for the development of reading programs, in their particular classroom environment, which will create a learning environment which is both exciting and interesting.

Teachers need to employ interesting techniques and methods, which may include new teaching mediums, to motivate students and to promote the enjoyment of reading. While good reading ability will allow students to better understand the text studied. Media can also help to motivate learners. Setyowati (2006, p. 64), takes the view that the use of various media can also help to avoid boredom in the teaching and learning process. Media including games, songs, pictures, flashcards, tape, radio, television, video, film, and slide over projectors can be used in the teaching-learning process, especially in improving vocabulary competence.

The ideas and opinions discussed above form the basis of this comprehensive study of; the effectiveness of Environment-Based Reading Material in Increasing Students' Vocabulary in EFL Learning in the Eighth Grade of Sumbawa District Junior High School.

\section{THEORETICAL FRAMEWORK}

\section{A. Environment-based Reading}

According to Tabatabaei \& Khalili (2014, p. 1368), reading is one of the most useful and necessary skills for daily life. People usually read if they want to gain some information. Teachers need reading text in order to teach reading in the classroom. To enhance students' interest in reading, the teacher must be able to design interesting reading material along with teaching strategies. The environmentally based reading material used in the study was comprised of four different types, namely; urban-based, marine-based, mountain-based, and rural-based reading material.

Environment-based reading material was developed using local topics. Each set of environment-based reading materials covers different topics. Urban environment-based material contained seven topics, namely; airport, shopping center, traditional market, traffic signs, traffic lights, Sultan's palace, Samota bridge, and bus stops. Marine environment-base material contained six topics, namely; coral, boat, fisherman, beach, containers, and cargo ships. Mountain environment-base material contained six topics, namely; waterfall, artificial beehives, deer, bamboo trees, horses, and teak wood trees. Rural environment-base material contained seven topics, namely; carpenter, hut, coconut, cow, rice field, corn plant, and fence.

Through environment-based reading material, students learn how to increase their vocabularies. The reading material contained simple vocabulary and simple sentences, making it easier for the students to understand, internalize and recall.

\section{B. Vocabulary Competence}

Goundar (2015, p. 292), suggests that, one of the major challenges for the teacher in teaching an EFL classroom is to implement strategies which will enable students to become independent learners. As independent learners, they then have the ability to improve their vocabulary on their own. Syafrizal (2018, p. 40), also suggests that, the teacher needs to manipulate some strategies to support the teaching and learning process.

Vocabulary competence is one of the main elements of EFL learning. Viera (2017, p. 91), states that the knowledge of vocabulary is essential in learning languages, and, similarly, Kumar (2018, p. 115), emphasizes that vocabulary knowledge is widely recognized as a vital aspect of second-language (L2), vocabulary acquisition and proficiency. Learners must achieve vocabulary competence if they want achieve a good language competence. Susanto (2017, p. 183), suggests that a learner with insufficient vocabulary size will not perform well in every aspect of language itself.

\section{RESEARCH METHOD}

\section{A. Participants}

Initially, 256 learners, from four different Sumbawa, Junior High School were selected for the study; each school with a different environment-base; that is urban, marine, mountain, and rural environments. The students were all enrolled in Grade 8 in the School Year 2019-2020. Both female and male students within the age range of 14-16 years old were selected, and this experimental group was taught using environment-based reading material. To assess their level of language proficiency the Preliminary English Test (PET), in the form of multiple-choice questions relating to reading text, was administered. From the results of this test 128 students were selected.

\section{B. Research Instruments}


The study used a quantitative descriptive research approach. Data was collected pre-test and post-test and effectiveness was measured by comparing the results. The tests were multiple-choice, using environment-based reading material. The multiple-choice test was divided as follows: (1) 20 multiple-choice questions based on environment-based urban reading material, (2) 20 multiple-choice questions based on environment-based marine reading material. 3) 20 multiple choice questions based on environment-based mountain reading material, and (4) 20 multiple-choice questions based on environment-based rural reading material. The environment-based reading material will be considered significant or effective if the post-test results are higher than the pretest results.

Descriptive research was used since the study aims to describe, using quantitative information from the result of the test, the participants' levels of English learning and vocabulary competence.

\section{Procedure of the Study}

The effectiveness of employing visualization for boosting students' reading competence was investigated using the following research methods. Prior to the commencement of the study, the students were assessed as to their suitability to participate, based on their proficiency in the English language. A Preliminary English Test (PET), in the form of multiple-choice answers based on reading text, was used to establish this.

The initial data for the study was collected from a test consisting of 20 multiple-choice answers relating to reading texts provided to the students: its aim being to establish the initial differences between learners. At the conclusion of the teaching program established for this study, a further test, comprised of 20 multiple-choice answers, based on the material and content covered throughout the course, was undertaken by the all students.

\section{Data Analysis}

The data from the reading test, which demonstrated the level of reading competence of the $8^{\text {th }}$ grade students of the junior high schools involved in the study, was analyzed using descriptive statistics. The SPSS version 24 program was employed to analyze the data.

Two types of statistical analysis were used to process the data derived from pre- and post-test of the participants, namely: descriptive and inferential statistics.

Descriptive statistics were used to gain the total score of each test, mean, minimum score, maximum score, standard error, and standard deviation. Inferential statistics with paired sample t-test were used to ascertain the individual significance of the pre-test and post-test averages.

\section{RESULTS AND DisCUSSION}

To addressee the research questions, at first, descriptive statistics were computed and displayed.

TABLE 1

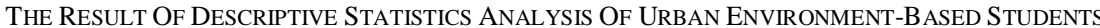

\begin{tabular}{|l|c|c|c|c|c|c|}
\hline & $\mathrm{N}$ & Minimum & Maximum & Sum & Mean & Std. Deviation \\
\hline Pre-test & 32 & 35 & 65 & 1735 & 54.22 & 8.043 \\
\hline Post-test & 32 & 70 & 90 & 2600 & 81.25 & 4.579 \\
\hline Valid N (list wise) & 32 & & & & & \\
\hline
\end{tabular}

As can be seen in table 1 , on the pre-test, the minimum score was 35 , and the maximum score was 65 , while on the post-test, the minimum score was 70 , and the maximum score was 90 . Furthermore, the mean score on the pre-test was 54.22, while on the post-test the mean score was 81.25. The increase of mean score after implementation of environment-based reading material was $49.85 \%$. Based on table 1 , we can see that the average rating of a post-test (81.25) was greater than the average score of a pre-test (54.22).

TABLE 2

THE RESUlt OF PAIRED SAMPLES T-TEST OF URBAN ENVIRONMENT-BASED STUDENTS

\begin{tabular}{|c|c|c|c|c|c|c|c|c|}
\hline & \multicolumn{5}{|c|}{ Paired Differences } & \multirow[t]{3}{*}{$\mathrm{t}$} & \multirow[t]{3}{*}{ df } & \multirow[t]{3}{*}{ Sig. (2-tailed) } \\
\hline & \multirow[b]{2}{*}{ Mean } & \multirow[b]{2}{*}{ Std. Deviation } & \multirow{2}{*}{$\begin{array}{l}\text { Std. Error } \\
\text { Mean }\end{array}$} & \multicolumn{2}{|c|}{$\begin{array}{l}95 \% \text { Confidence Interval of } \\
\text { the Difference }\end{array}$} & & & \\
\hline & & & & Lower & Upper & & & \\
\hline $\begin{array}{l}\text { Pretest - } \\
\text { Posttest }\end{array}$ & -27.031 & 7.605 & 1.344 & -29.773 & -24.289 & -20.106 & 31 & .000 \\
\hline
\end{tabular}


Based on the analysis of data displayed in Table 2, the result showed that the paired sample t-test on environmentbased urban found sig. (2-tailed) 0.000 , value $\mathrm{T}_{\text {count }}-20.106$, it can be positive, meaning 29.118, and the value of mean paired differences was -27.031. Data obtained that sig. (2-tailed) $0.000<0.05$, and value $\mathrm{T}_{\text {count }} 29.118>\mathrm{T}_{\text {table }} 2.744$, for the significance level $\alpha=0.05 \mathrm{n}=32$. It concluded that, the use of environment-based urban reading material was significant, on vocabulary competence, for the eighth grade of Junior High School in the Sumbawa District.
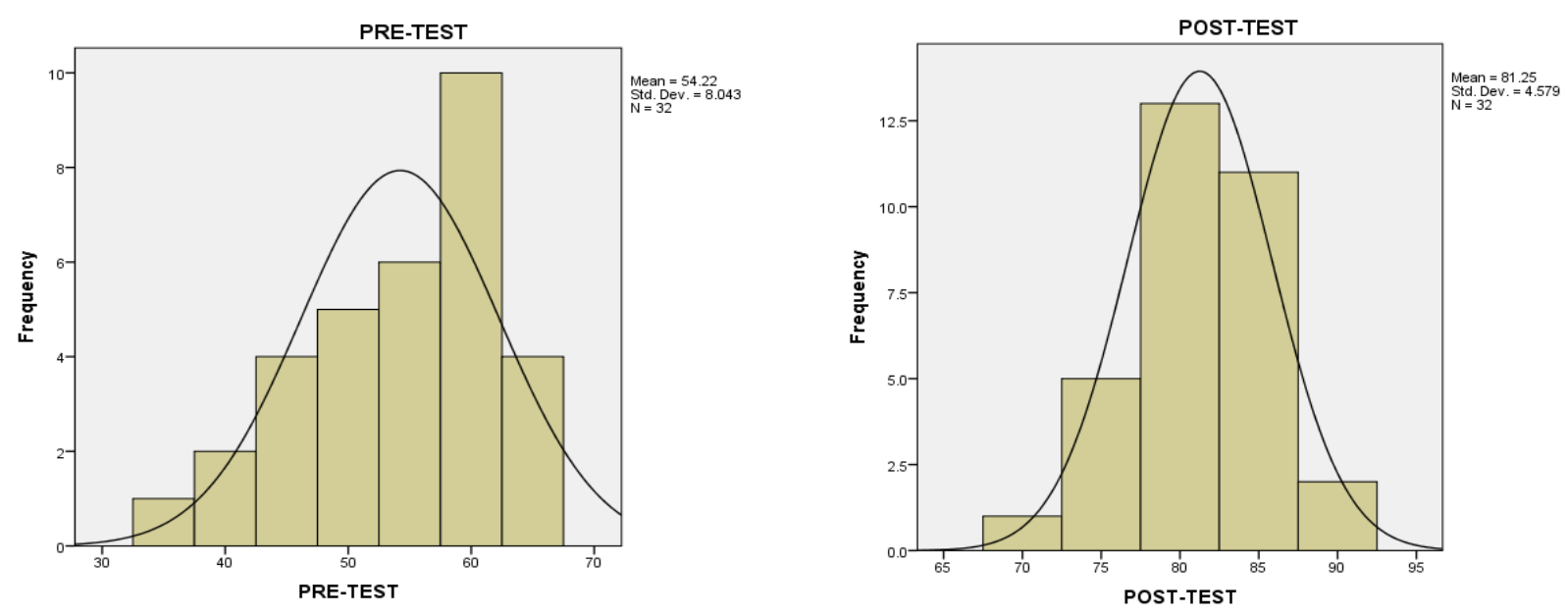

Figure 1. Normality of the distribution of the Data Urban Environment-Based

TABLE 3

THE RESULT OF MARINE ENVIRONMENT-BASED STUDENTS

\begin{tabular}{|l|c|c|c|c|c|c|}
\hline & $\mathrm{N}$ & Minimum & Maximum & Sum & Mean & Std. Deviation \\
\hline Pre-test & 32 & 45 & 70 & 1735 & 54.22 & 6.364 \\
\hline Post-test & 32 & 70 & 90 & 2465 & 77.03 & 5.215 \\
\hline Valid N (list wise) & 32 & & & & & \\
\hline
\end{tabular}

Based on Table 3 where the result of descriptive statistics of Marine Environment-Based was the minimum score 45, and the maximum score was 70 on the pre-test, the minimum score was 70, and the maximum score was 90 on the posttest. Furthermore, the mean score on the pre-test was 54.22, and the mean score on the post-test was 77.03 and the increase of mean score after implementation of environment-based reading material was $42.06 \%$. This shows that the average post-test score (77.03) was greater than the average pre-test score (54.22).

TABLE 4

THE RESUlt OF PAIRED SAMPLES T-TEST OF MARINE ENVIRONMENT-BASED STUDENTS

\begin{tabular}{|c|c|c|c|c|c|c|c|c|}
\hline & \multicolumn{5}{|c|}{ Paired Differences } & \multirow[t]{3}{*}{$\mathrm{t}$} & \multirow[t]{3}{*}{$\mathrm{df}$} & \multirow[t]{3}{*}{ Sig. (2-tailed) } \\
\hline & \multirow[b]{2}{*}{ Mean } & \multirow{2}{*}{$\begin{array}{c}\text { Std. } \\
\text { Deviation }\end{array}$} & \multirow{2}{*}{$\begin{array}{l}\text { Std. Error } \\
\text { Mean }\end{array}$} & \multicolumn{2}{|c|}{$\begin{array}{l}95 \% \text { Confidence Interval of } \\
\text { the Difference }\end{array}$} & & & \\
\hline & & & & Lower & Upper & & & \\
\hline $\begin{array}{l}\text { Pretest - } \\
\text { Posttest }\end{array}$ & -22.813 & 5.527 & .977 & -24.805 & -20.820 & -23.350 & 31 & .000 \\
\hline
\end{tabular}

Based on analysis of data shown in Table 4, the result of the paired sample t-test on environment-based marine found sig. (2-tailed) 0.000 , value $\mathrm{T}_{\text {count }}-23.350$, it can be positive, meaning 23.350 , and the value of mean paired differences was -22.813 . Data obtained that sig. (2-tailed) $0.000<0.05$, and value $\mathrm{T}_{\text {count }} 23.350>\mathrm{T}_{\text {table }} 2.744$, for the significance level $\alpha=0.05 \mathrm{n}=32$. It concluded that the use of environment-based marine reading material was significant in vocabulary competence for the eighth grade of Junior High School in the Sumbawa District. 

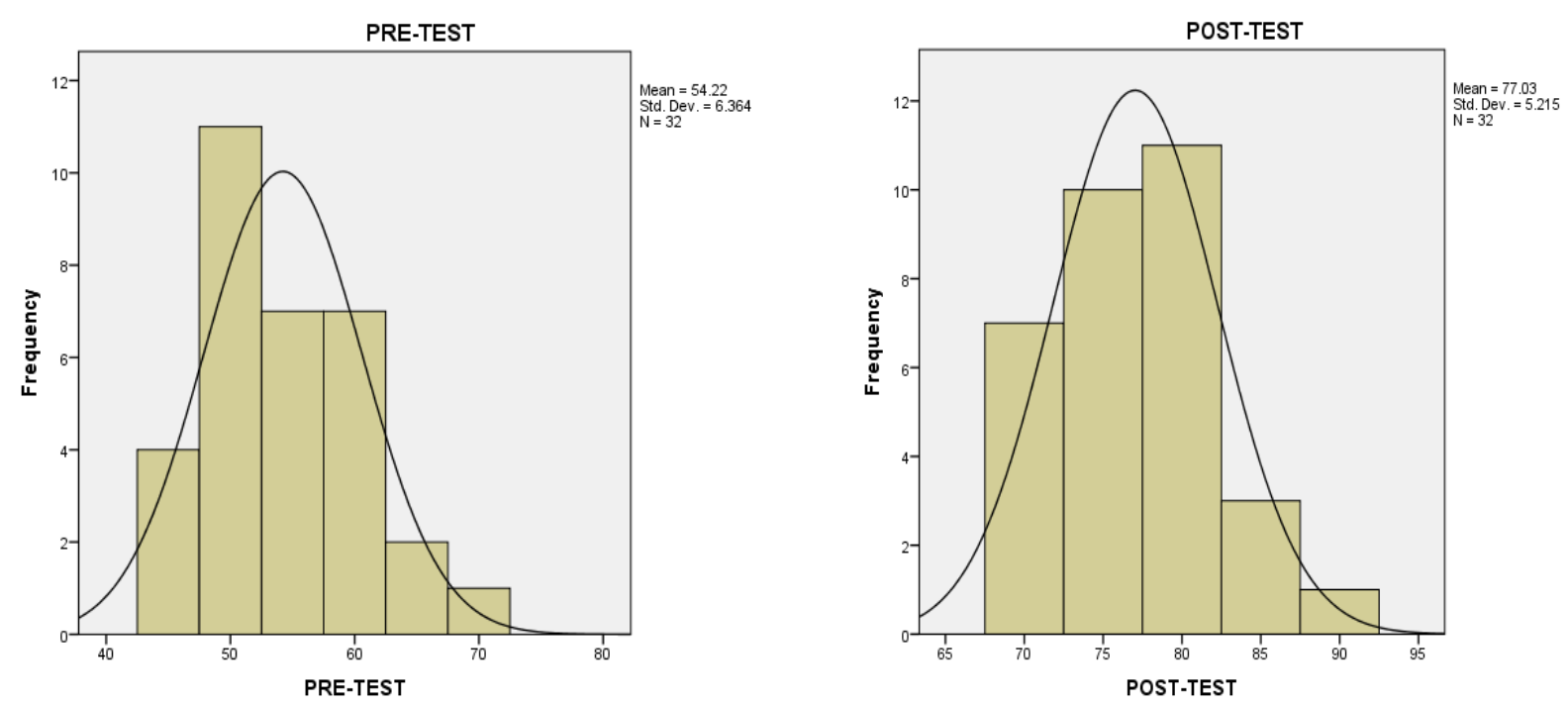

Figure 2. Normality of the Distribution of the Data Marine Environment-Based

TABLE 5

THE RESUlt OF MOUNTAIN ENVIRONMENT-BASED STUDENTS

\begin{tabular}{|l|c|c|c|c|c|c|}
\hline & $\mathrm{N}$ & Minimum & Maximum & Sum & Mean & Std. Deviation \\
\hline Pre-test & 32 & 40 & 65 & 1765 & 55.16 & 6.658 \\
\hline Post-test & 32 & 70 & 85 & 2470 & 77.19 & 4.741 \\
\hline Valid N (list wise) & 32 & & & & & \\
\hline
\end{tabular}

Table 5, shows that, on pre-test, the minimum score was 40, and the maximum score was 65 , and on the post-test, the minimum score was 70 , and the maximum score was 85 . Furthermore, the mean score on the pre-test was 55.16 , and the mean score on the post-test was 77.19. The increase of mean score after implementation of environment-based reading material was $39.93 \%$. This indicated that the average the post-test score (77.19) was greater than the average score of pre-test (55.16).

TABLE 6

THE RESUlt OF PAIRED SAMPLES T-TEST OF MOUNTAIN ENVIRONMENT-B ASED STUDENTS

\begin{tabular}{|c|c|c|c|c|c|c|c|c|}
\hline & \multicolumn{5}{|c|}{ Paired Differences } & \multirow[t]{3}{*}{$\mathrm{t}$} & \multirow[t]{3}{*}{$\mathrm{df}$} & \multirow[t]{3}{*}{ Sig. (2-tailed) } \\
\hline & \multirow[b]{2}{*}{ Mean } & \multirow{2}{*}{$\begin{array}{c}\text { Std. } \\
\text { Deviation }\end{array}$} & \multirow{2}{*}{$\begin{array}{l}\text { Std. Error } \\
\text { Mean }\end{array}$} & \multicolumn{2}{|c|}{$\begin{array}{l}\text { 95\% Confidence Interval of } \\
\text { the Difference }\end{array}$} & & & \\
\hline & & & & Lower & Upper & & & \\
\hline $\begin{array}{l}\text { Pretest - } \\
\text { Posttest }\end{array}$ & -22.813 & 5.527 & .977 & -24.805 & -20.820 & -23.350 & 31 & .000 \\
\hline
\end{tabular}

Based on the result of the data calculation, the data shows in Table 6 was found sig. (2-tailed) 0.000 , value $\mathrm{T}_{\text {count }}$ 23.350, it can be positive, meaning 23.350, and the value of mean paired differences was -22.813 . Data obtained that sig. (2-tailed) $0.000<0.05$, and value $\mathrm{T}_{\text {count }} 23.350>\mathrm{T}_{\text {table }} 2.744$, for the significance level $\alpha=0.05 \mathrm{n}=32$. It can be concluded that the use of environment-based mountain reading material was significant on vocabulary competence for the eighth grade of Junior High School in the Sumbawa District. 

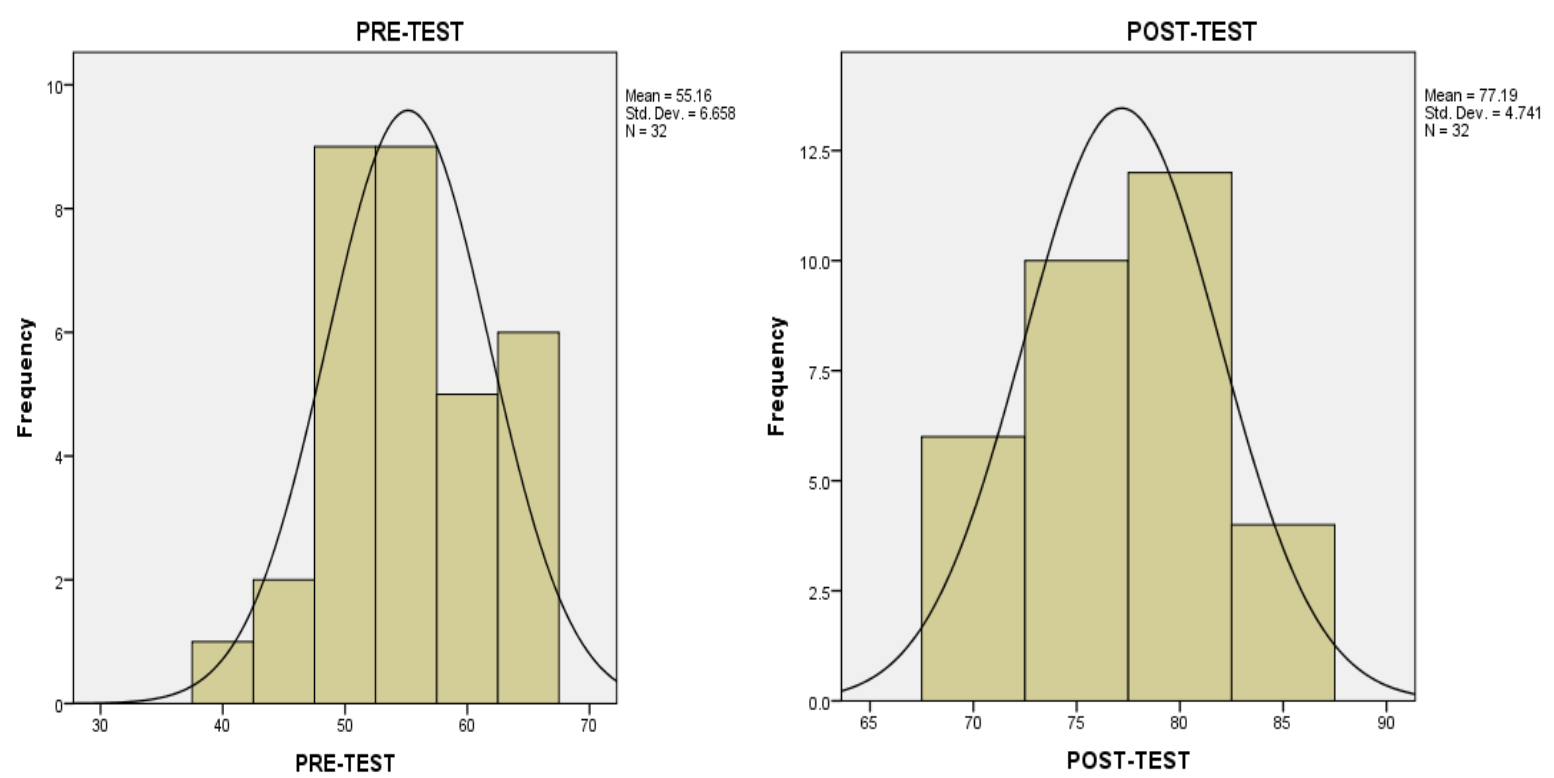

Figure 3. Normality of the distribution of the Data Mountain Environment-Based

TABLE 7

THE RESULT OF RURAL ENVIRONMENT-BASED STUDENTS

\begin{tabular}{|l|c|c|c|c|c|c|}
\hline & $\mathrm{N}$ & Minimum & Maximum & Sum & Mean & Std. Deviation \\
\hline Pre-test & 32 & 40 & 65 & 1685 & 52.66 & 7.404 \\
\hline Post-test & 32 & 70 & 85 & 2445 & 76.41 & 5.272 \\
\hline Valid N (list wise) & 32 & & & & & \\
\hline
\end{tabular}

As can be seen in table 7, on the pre-test, the minimum score was 40 and the maximum score was 65 , while on the post-test, the minimum score was 70 and the maximum score was 85 . Furthermore, the mean score on the pre-test was 52.66 while on the post-test the mean score was 76.41. The increase of mean score after implementation of the rural environment-based reading material was $45.1 \%$. Table 7 shows that the average rating of a post-test (76.41) was greater than the average score of pre-test (52.66).

TABLE 8

THE RESult Of PAIRED SAMPLES T-TEST OF RuRAL ENVIRONMENT-BASED STUdENTS

\begin{tabular}{|c|c|c|c|c|c|c|c|c|}
\hline & \multicolumn{5}{|c|}{ Paired Differences } & $\mathrm{t}$ & df & Sig. (2-tailed) \\
\hline & \multirow[b]{2}{*}{ Mean } & \multirow{2}{*}{$\begin{array}{c}\text { Std. } \\
\text { Deviation }\end{array}$} & \multirow{2}{*}{$\begin{array}{l}\text { Std. Error } \\
\text { Mean }\end{array}$} & \multicolumn{2}{|c|}{$\begin{array}{l}95 \% \text { Confidence Interval of } \\
\text { the Difference }\end{array}$} & & & \\
\hline & & & & Lower & Upper & & & \\
\hline $\begin{array}{l}\text { Pretest - } \\
\text { Posttest }\end{array}$ & -23.750 & 6.350 & 1.123 & -26.039 & -21.461 & -21.158 & 31 & .000 \\
\hline
\end{tabular}

The data presented, in Table 8, shows that the result of the paired sample t-test on the rural environment-based found sig. (2-tailed) 0.000 , value $\mathrm{T}_{\text {count }}-21.158$, it can be positive, meaning 21.158 , and value of mean paired differences was 23.750. Data obtained that sig. (2-tailed) $0.000<0.05$, and value $\mathrm{T}_{\text {count }} 21.158>\mathrm{T}_{\text {table }} 2.744$ for the significance level $\alpha$ $=0.05 \mathrm{n}=32$. It can be concluded that the use of environment-based rural reading material was significant on vocabulary competence for the eighth grade of Junior High School in the Sumbawa District. 

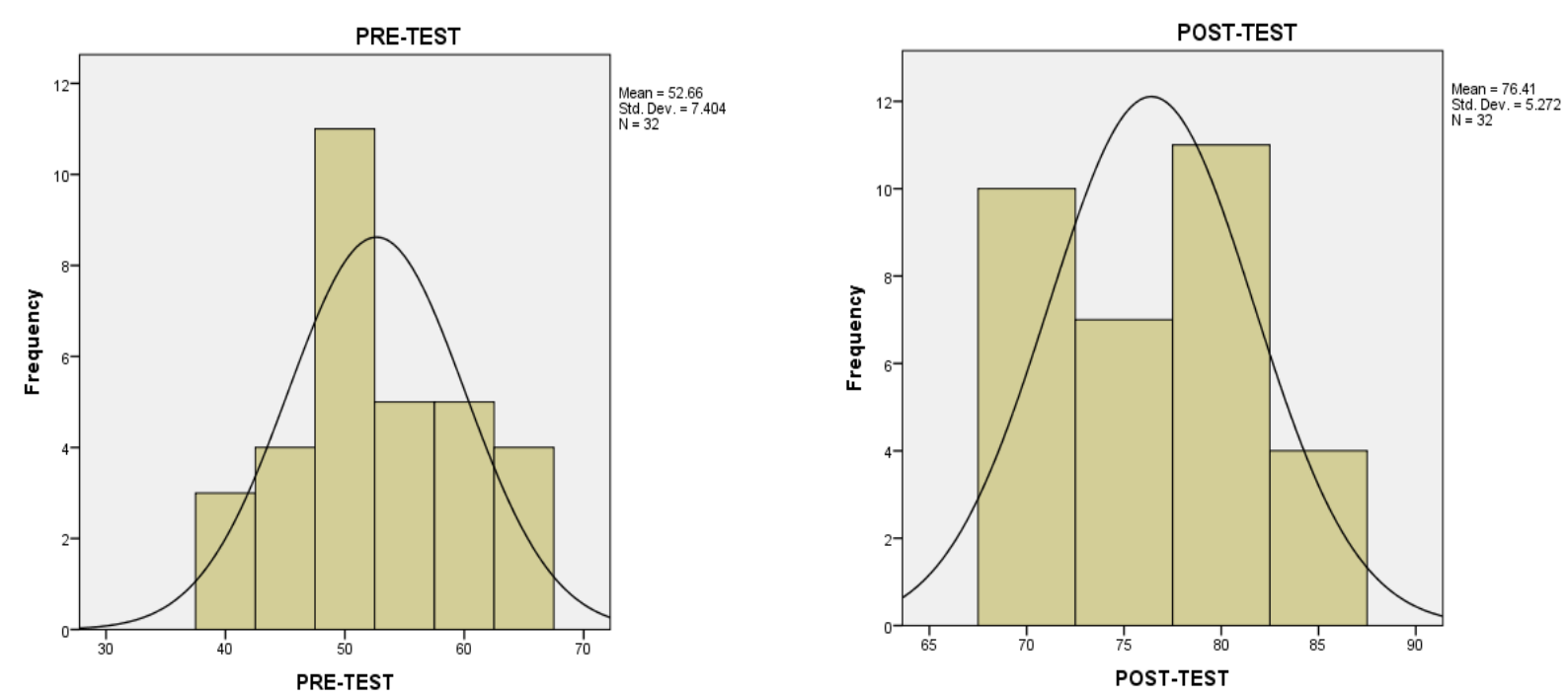

Figure 4. Normality of the Distribution of the Data Rural Environment-Based

\section{CONCLUSION, ImPliCATIONS \& SUGGESTIONS}

\section{A. Conclusion}

Vocabulary is one of the most important elements of language learning. According to Achmad (2013, p. 80), states the English vocabularies are including to the core competence in learning English. In the course of the study strategies and methods were implemented, by teachers, to enhance or increase learners' vocabularies. Some strategies implemented in the teaching and learning process based on the environment-based reading material, were task-based. Namely, vocabulary-learning through activities. This included retelling the story or information contained in the text or visual presentation, such as pictures and drawings, presented to the class. More active tasks were also employed to maintain the students' motivation and enjoyment. These included vocabulary games such as Hangman, and Bingo, as well as songs with appropriate actions, such as, Heads, Shoulders, Knees and Toes.

Based on the result of data analysis, the researcher found that the Environment-based reading materials were significant for the eighth grade of Junior High School in the Sumbawa District. This research also details the planning process and the development of the environment-based reading material that was used in the teaching and learning process. The use of environment-based reading material proved significant in the results of the study. Students who participated in the environmentally-based reading program demonstrated an increased vocabulary competence when compared with to students who did not participate.

\section{B. Implications}

The present study has some implications for Sumbawa EFL teachers, students, and those involved in the development of teaching resources. The findings of this study suggest that environment-based teaching material has the potential to impact positively on the vocabulary competence of Sumbawa District EFL learners. In addition, the integration of environment-based teaching material and enjoyable, stimulating language based activities can inspire students to actively participate in the learning process, particularly in vocabulary learning. The research result gives further credence to the basic premise that the use of environment-based reading material has a significant influence on the learning outcomes of students' English vocabulary competence. Development of the environment-based reading material was based on the environment vocabulary of EFL learners who participated, namely; the environment-based urban reading material was based on the environment-based urban vocabulary of the students involved; the environment-based marine reading material was based on the environment-based marine vocabulary on the students involved; the environment-based mountain reading material was based on the environment-based mountain vocabulary on the students involved, and environment-based rural reading material was based on the environment-based rural vocabulary of the students involved.

\section{Suggestions}

Based on the findings obtained in this study, the following topics were suggested as being worthy of further research.

- Teaching materials; in order to facilitate the enjoyment of EFL learners in the learning process, development of appropriate teaching material is essential.

- Motivation; the exploration and potential use of environment-based teaching material to simulate students' interest and motivate the students' active participation in the learning process of foreign or second language learning. 
- Strategies and method; the further development of strategies and methods which encourage the enhancement of students' vocabulary competence and improvement in their reading comprehension.

\section{REFERENCES}

[1] Achmad, S. (2013). Developing English Vocabulary Mastery through Meaningful Learning Approach An Applied Linguistics Study at Competitive Class of Junior High Schools in Gorontalo City, Indonesia. International Journal of Linguistics, 5(5), $75-$ 97. doi:10.5296/ijl.v5i5.4454.

[2] Akyol, H., Çakiroglu, A., \& Kuruyer, H. G. (2014). A Study on the Development of Reading Skills of the Students Having Difficulty in Reading: Enrichment Reading Program. International Electronic Journal of Elementary Education, 6(2), $199-212$.

[3] Alqahtani, M. (2015). The importance of vocabulary in language learning and how to be taught. International Journal of Teaching and Education., III(3), 21-34. doi:10.20472/TE.2015.3.3.002.

[4] Asmawati, A. (2015). The Effectiveness of Skimming - Scanning Strategy in Improving Students' Reading Comprehension at The Second Grade of SMK Darussalam Makassar. ETERNAL (English, Teaching, Learning, and Research Journal), 1(1), 6983

[5] Bai, Z. (2018). An Analysis of English Vocabulary Learning Strategies. Journal of Language Teaching and Research., 9(4), 853-859. doi:10.17507/jltr.0904.24.

[6] Duff, D., Tomblin, J. B., \& Catts, H. (2015). The Influence of Reading on Vocabulary Growth: A Case for a Matthew Effect. Journal of Speech, Language, and Hearing Research, 58, 853-864.

[7] Goundar, P. R. (2015). Vocabulary Learning Strategies of English as Foreign Language (EFL) Learners: a Literature Review. International Journal of Humanities and Cultural Studies, 2(2), 292-301.

[8] Kumar, D. A., \& Dhanavel, S. P. (2018). Exploring differences in vocabulary knowledge of semi-urban ESL undergraduate students. Calidoscópio, 16(1), 114-121. doi:10.4013/cld.2018.161.10.

[9] Mokhtari, R. (2014). The Comparative Study of Literary vs. Non-literary Text and Iranian EFL Learners ${ }^{\text {ee }}$ Performance on Cloze Tests of Inference. Journal of Language Teaching and Research., 5(1), 163-174. doi:10.4304/j1tr.5.1.163-174.

[10] Pietilä, P., \& Merikivi, R. (2014). The Impact of Free-time Reading on Foreign Language Vocabulary Development. Journal of Language Teaching and Research, 5(1), 28-36. doi:10.4304/j1tr.5.1.28-36.

[11] Sanati, Z. (2020). The Effects of Visualization Training Techniques on Reading Comprehension Ability of Iranian Intermediate EFL Learners. Journal of Language Teaching and Research, 11(1), 73-85. doi:10.17507/j1tr.1101.09.

[12] Satyawati, U. M. (2019). Assessment of English Vocabulary Mastery through Environment-Based Image Media on the 7th Grade Students. Asian EFL Journal, 25(5.1), 240-260.

[13] Setyowati, L. (2006). Instructional media in the Teaching of English for Adult Learners. Syntagma, 1(1), 58-67.

[14] Susanto, A. (2017). The Teaching of Vocabulary: A Perspective. Jurnal KATA, 1(2), 182-191.

[15] Syafrizal, \& Haerudin. (2018). The Implementation of Vocabulary Building Strategy in Teaching English Vocabulary to Young Learners. Journal of English Language Teaching, 5(1), 40-48. doi:10.33394/jo-elt.v5i1.2296.

[16] Tabatabaei, O., \& Khalili, S. (2014). The Effect of Concept Mapping on Iranian Pre-intermediate L2 Reading Comprehension. Journal of Language Teaching and Research, 5(6), 1368-1380. doi:10.4304/jltr.5.6.1368-1380.

[17] Taheri, M. (2014). The Effect of Using Language Games on Vocabulary Retention of Iranian Elementary EFL Learners. Journal of Language Teaching and Research, Vol. 5, No. 3, pp. 544-549, May 2014, 5(3), 544-549. doi:10.4304/j1tr.5.3.544549

[18] Tanyer, S., \& Ozturk, Y. (2014). Pre-service English Teachers ${ }^{e e}$ Vocabulary Learning Strategy Use and Vocabulary Size: A Cross-sectional Evaluation. Journal of Language Teaching and Research, 5(1), 37-45. doi:10.4304/jltr.5.1.37-45.

[19] Thao, V. T., Mai, L. H., \& Ngoc, L. T. (2014). An Inquiry into Students' Application of Metacognitive Strategies in Reading Technical Materials. Journal of Language Teaching and Research, 5(6), 1283-1291. doi:10.4304/jltr.5.6.1283-1291.

[20] Viera, R. T. (2017). Vocabulary knowledge in the production of written texts: a case study on EFL language learners. Revista Tecnológica ESPOL - RTE, 30(3), 89-105.

Umar was born in Bajo, Indonesia. He is a lecturer at the English Department at STKIP Paracendekia NW Sumbawa. He accomplished his master degree in 2013 focusing on the English Language Education at UNDIKSHA Singaraja, Bali, Indonesia His research interests are speaking strategies, language learning strategies, reading in a foreign language, and academic writing. He is currently registered as a doctoral candidate in linguistics at Udayana University majoring in learning and language teaching studies.

I Nengah Sudipa is a lecturer at the Udayana University. His research interests are linguistics transformation and structural by modern development, micro linguistics, and semantics structural. Email: nengahsudipa@yahoo.co.id. Address: College of Udayana University, Doctoral Linguistics Studies, Jln. P. Nias, 13 Denpasar, Bali, Indonesia. 